\title{
Redescription and molecular analysis of Neoechinorhynchus (Neoechinorhynchus) johnii Yamaguti, 1939 (Acanthocephala, Neoechinorhynchidae) from the Pacific Ocean off Vietnam
}

\author{
Omar M. Amin ${ }^{1, *}$, Anshu Chaudhary ${ }^{2}$, Richard Heckmann ${ }^{3}$, Nguyen V. Ha ${ }^{4}$, and Hridaya S. Singh ${ }^{2}$ \\ ${ }^{1}$ Institute of Parasitic Diseases, 11445 E. Via Linda 2-419, Scottsdale, AZ 85259, USA \\ ${ }^{2}$ Molecular Taxonomy Laboratory, Department of Zoology, Chaudhary Charan Singh University, Meerut, Uttar Pradesh, 250004, India \\ ${ }^{3}$ Department of Biology, Brigham Young University, 1114 MLBM, Provo, UT 84602, USA \\ ${ }^{4}$ Department of Parasitology, Institute of Ecology and Biological Resources (IEBR), Vietnam Academy of Science and Technology, \\ 18 Hoang Quoc Viet, Cau Giay, Hanoi, Vietnam
}

Received 25 March 2019, Accepted 21 June 2019, Published online 23 July 2019

\begin{abstract}
Neoechinorhynchus (Neoechinorhynchus) johnii Yamaguti, 1939 is redescribed from Eleutheronema tetradactylum (Polynemidae), Johnius carouna (Sciaenidae), Johnius sp., and Otolithes ruber (Sciaenidae) along the north and south coasts of Vietnam. Our description completes missing and inadequate information in the original descriptions and line drawings from Johnius goma in Japan and from Pseudosciaena diacanthus in the Indian Ocean. We add new information documented by scanning electron microscopy (SEM) and photomicroscopy, and explore the wide morphological diversity attributed to host species. The redescription includes: worms cylindrical with round proboscis with prominent apical organ, and large anterior hooks distant from small middle and posterior hooks; neck longer than the proboscis, nucleated lemnisci subequal, and receptacle with large basal triangulate cephalic ganglion and attached para-receptacle structure (PRS); male reproductive system in posterior half of trunk; adult females with introvert genital vestibule; and eggs spherical or rectangular. Gallium cuts and X-ray scans of hooks show high concentrations of sulfur on edge layer aiding in forming hardened calcium phosphate apatite of that layer with calcium and phosphorus in higher concentration in central part of hook. Molecular results consistently yielded a strongly supported distinct clade for the Neoechinorhynchus species from Vietnam for both $18 \mathrm{~S}$ gene and the ITS1-5.8S-ITS2 region of ribosomal RNA. Phylogenetic analysis demonstrated that $N$. johnii occupies a separate position in the trees, probably indicating an Asian origin of this species.
\end{abstract}

Key words: Acanthocephala, Neoechinorhynchus johnii, Diversity, Molecular description, Hosts and distribution.

Résumé - Redescription et analyse moléculaire de Neoechinorhynchus (Neoechinorhynchus) johnii Yamaguti, 1939 (Acanthocephala, Neoechinorhynchidae) de l'océan Pacifique au large du Viêt Nam. Neoechinorhynchus (Neoechinorhynchus) johnii Yamaguti, 1939 est redécrit de Eleutheronema tetradactylum (Polynemidae), Johnius carouna (Sciaenidae), Johnius sp. et Otolithes ruber (Sciaenidae) des côtes nord et sud du Viêt Nam. Notre description complète les informations manquantes et inadéquates dans les descriptions originales et les dessins au trait de spécimens de Johnius goma au Japon et de Pseudosciaena diacanthus de l'océan Indien. Nous ajoutons de nouvelles informations par microscopie électronique à balayage et photomicroscopie, et explorons la grande diversité morphologique attribuée aux espèces hôtes. La nouvelle description comprend : vers cylindriques à trompe arrondie avec un organe apical proéminent et de grands crochets antérieurs éloignés des petits crochets médians et postérieurs ; cou plus long que le proboscis, lemnisques nucléés subégaux, et réceptacle avec un grand ganglion céphalique triangulaire basal et une structure de para-réceptacle attachée ; système reproducteur mâle dans la moitié postérieure du tronc ; femelles adultes avec vestibule génital introverti ; oeufs sphériques ou rectangulaires. Les coupes au gallium et les analyses aux rayons $\mathrm{X}$ des crochets montrent de fortes concentrations de soufre sur la couche marginale, contribuant à la formation d'apatite de phosphate de calcium durci de cette couche, avec une concentration plus élevée de calcium et de phosphore dans la partie centrale du crochet. Les résultats moléculaires pour le gène $18 \mathrm{~S}$ et les régions ITS1-5.8S-ITS2 de l'ARN ribosomal ont régulièrement montré un clade distinct et fortement soutenu pour les espèces de Neoechinorhynchus du Viêt Nam. L'analyse phylogénétique a démontré que $N$. johnii occupe une position distincte dans les arbres, indiquant probablement une origine asiatique de cette espèce.

*Corresponding author: omaramin@aol.com

This is an Open Access article distributed under the terms of the Creative Commons Attribution License (http://creativecommons.org/licenses/by/4.0), which permits unrestricted use, distribution, and reproduction in any medium, provided the original work is properly cited. 


\section{Introduction}

Most of the recent taxonomic work on the Acanthocephala from Vietnam was reported by the Amin-Heckmann-Ha team since 2000. A number of acanthocephalan species from freshwater fish, amphibians, reptiles, birds, and mammals were previously described in Vietnam [5, 10-14]. Additionally, 11 species of acanthocephalans were collected from marine fish off the eastern seaboard of Vietnam in Halong Bay in 2008 and 2009. Of these, six new species of Neoechinorhynchus Stiles \& Hassall 1905, one new species of Heterosentis Van Cleave, 1931, and two new species of Rhadinorhynchus Lühe 1911 were described $[9,15,16]$. Four other species of Echinorhynchid acanthocephalans from marine fishes in Halong Bay were also described [6], and five other new species from fishes and amphibians of eight collected host species were described [18]. Three other species of Rhadinorhynchus and one species of Gorgorhynchus were otherwise previously reported from marine fishes in Vietnam [20].

Fifteen species of acanthocephalans in five families were more recently collected from fishes in the Pacific and amphibians in central Vietnam in 2016 and 2017. The revision of the genus Neoechinorhynchus and the erection of two subgenera $[2,3]$ complement the above reports to produce the present account redescribing $N$. johnii using SEM and photomicroscopy. We also report new features including results of metal analysis of hooks (energy dispersive analysis for X-ray, EDAX) and expand the host and geographical distribution of the species. We also include the molecular description of N. johnii Yamaguti, 1939 and describe its phylogenetic relationships.

\section{Materials and methods Collections}

Specimens were collected using gill nets from research vessels off shore at noted collection sites. Information on the collections of specimens of $N$. johnii is presented in Table 1.

\section{Processing for microscopical studies}

Freshly collected acanthocephalans were extended in water until proboscides were everted, and fixed in 70\% ethanol for transport to our Institute of Parasitic Diseases (IPD) in Arizona, USA for processing and further studies. Worms were punctured with a fine needle and subsequently stained in Mayer's acid carmine, destained in $4 \%$ hydrochloric acid in $70 \%$ ethanol, dehydrated in ascending concentrations of ethanol reaching $100 \%$ (24 h each), and cleared in 100\% xylene then in 50\% Canada balsam and $50 \%$ xylene ( $24 \mathrm{~h}$ each). Whole worms were then mounted in Canada balsam. Measurements are in micrometers, unless otherwise noted; the range is followed by the mean values between parentheses. Width measurements represent maximum width. Trunk length does not include proboscis, neck, or bursa.

Voucher specimens were deposited in the University of Nebraska's State Museum's Harold W. Manter Laboratory (HWML) collection in Lincoln, Nebraska, USA.

\section{Scanning electron microscopy (SEM)}

Specimens that had been fixed and stored in $70 \%$ ethanol were processed for SEM following standard methods [29]. These included critical point drying (CPD) in sample baskets and mounting on SEM sample mounts (stubs) using conductive double-sided carbon tape. Samples were coated with gold and palladium for 3 min using a Polaron \#3500 sputter coater (Quorum (Q150 TES) https://www.quorumtech.com) establishing an approximate thickness of $20 \mathrm{~nm}$. Samples were placed and observed in an FEI Helios Dual Beam Nanolab 600 (FEI, Hillsboro, Oregon) Scanning Electron Microscope, with digital images obtained in the Nanolab software system (FEI, Hillsboro, Oregon), and then transferred to a USB for future reference. Samples were received under low vacuum conditions using $10 \mathrm{kV}$, spot size 2, 0.7 Torr using a GSE detector.

\section{X-ray microanalysis using energy dispersive analysis for X-ray (EDAX)}

Standard methods were used for preparation, similar to the SEM procedure. Specimens were examined and positioned with the above SEM instrument which was equipped with a Phoenix energy-dispersive X-ray analyzer (FEI, Hillsboro, Oregon). $\mathrm{X}$-ray spot analysis and live scan analysis were performed at $16 \mathrm{kV}$ with a spot size of five and results were recorded on charts and stored with digital imaging software attached to a computer. The TEAM* (Texture and Elemental Analytical Microscopy) software system (FEI, Hillsboro, Oregon) was used. Data were stored on a USB for future analysis. The data included weight percent and atom percent of the detected elements following correction factors.

\section{Ion sectioning of hooks}

A dual-beam SEM with a gallium (Ga) ion source (GIS) was used for the liquid ion metal source (LIMS) part of the process. The hooks of the acanthocephalans were centered on the SEM stage and cross-sectioned using a probe current between $0.2 \mathrm{nA}$ and $2.1 \mathrm{nA}$ according to the rate at which the area was cut. The time of cutting was based on the nature and sensitivity of the tissue. Following the initial cut, the sample also went through a milling process to obtain a smooth surface. The cut was then analyzed with X-ray at the tip, middle, and base of hooks for chemical ions with an electron beam (Tungsten) to obtain an X-ray spectrum. Results were stored with the attached imaging software then transferred to a USB for future use. The intensity of the GIS was variable, according to the nature of the material being cut.

\section{Molecular methods}

Genomic DNA of the worms preserved in $95 \%$ ethanol was extracted individually using a DNeasy ${ }^{\mathrm{TM}}$ Blood and Tissue kit (Qiagen, Germany), according to the manufacturer's instructions. Isolated DNA was amplified by PCR using the primer pairs: Worm A (5'-GCGAATGGCTCATTAAATCAG-3'), 270R (5'-CCGTCAATTCCTTTAAGT-3') [30] for the $18 \mathrm{~S}$ 
Table 1. Host and geographical distribution of Neoechinorhynchus johnii in the Pacific Ocean off Vietnam.

\begin{tabular}{|c|c|c|c|c|}
\hline Hosts & Specimens & Date & Location & Coordinates \\
\hline \multirow[t]{2}{*}{ Eleutheronema tetradactylus (Shaw) } & $3 \circ \circ$ in $1 / 1$ fish & 2016 & Vung Tau & $10^{\circ} 23^{\prime} \mathrm{N}, 107^{\circ} 7^{\prime} \mathrm{E}$ \\
\hline & $4 \widehat{0} \widehat{0}, 8$ 우 in $3 / 12$ fish & July, 2017 & Bac Lieu & $9^{\circ} 15^{\prime} \mathrm{N}, 105^{\circ} 45^{\prime} \mathrm{E}$ \\
\hline \multirow[t]{2}{*}{ Johnius carouna (Cuvier) } & $11 \hat{\jmath} \widehat{\jmath}, 14$ 우 & Oct., 2017 & Nha Trang & $12^{\circ} 15^{\prime} \mathrm{N}, 109^{\circ} 11^{\prime} \mathrm{E}$ \\
\hline & 5 우 in $1 / 10$ fish & July, 2017 & Bac Lieu & $9^{\circ} 15^{\prime} \mathrm{N}, 105^{\circ} 45^{\prime} \mathrm{E}$ \\
\hline Johnius sp. & 10,1 우 in 1 fish & March, 2017 & Tien Yen & $21^{\circ} 20^{\prime} \mathrm{N}, 107^{\circ} 24^{\prime} \mathrm{E}$ \\
\hline Otolithes ruber (Bloch \& Schneider) & $3 \widehat{\circ})^{2}, 5$ 우 & May, 2017 & Quang Binh & $17^{\circ} 30^{\prime} \mathrm{N}, 106^{\circ} 20^{\prime} \mathrm{E}$ \\
\hline Total & $20 \hat{\jmath} \widehat{\jmath}, 40$ + & & & \\
\hline
\end{tabular}

gene; and BD1 (5'-GTCGTAACAAGGTTTCCGTA-3') and BD2 (5'-TATGCTTAAATTCAGCGGGT-3') [23] for the ITS1+5.8S+ITS2 region. Amplification of the PCR reactions was carried in a $25 \mu \mathrm{L}$ reaction mixture containing $3 \mu \mathrm{L}$ DNA, $2.5 \mu \mathrm{L}$ of $10 \mathrm{X}$ Taq buffer (Biotools, Madrid, Spain), $1 \mu \mathrm{L}$ of Taq polymerase (1 U, Biotools), $3 \mu \mathrm{L}$ of deoxyribonucleoside triphosphates, $1 \mu \mathrm{L}$ of each forward and reverse primer, and $13.5 \mu \mathrm{L}$ of water. PCR cycling parameters comprised an initial denaturation at $94{ }^{\circ} \mathrm{C}$ for $3 \mathrm{~min}$, followed by 40 cycles of $94{ }^{\circ} \mathrm{C}$ for $45 \mathrm{~s}, 55^{\circ} \mathrm{C}$ for $45 \mathrm{~s}, 72^{\circ} \mathrm{C}$ for $1 \mathrm{~min}$, and subsequent final elongation at $72{ }^{\circ} \mathrm{C}$ for $10 \mathrm{~min}$, then stored at $4{ }^{\circ} \mathrm{C}$. Amplification products were electrophoresed through $1 \%$ agarose gel in TAE buffer and examined under ultraviolet light. The amplified DNA was then purified with the Purelink ${ }^{\mathrm{TM}}$ Quick Gel Extraction and PCR Purification Combo Kit (Invitrogen). Obtained amplification products were sequenced with the Big Dye Terminator v. 3.1 cycle sequencing kit in an ABI 3130 Genetic Analyzer, Applied Biosystems, using the above-mentioned primers.

Alignment and analysis of sequences obtained during the study were carried out using BioEdit, version 7.2.5 [26]. Sequences of $18 \mathrm{~S}$ and the ITS1+5.8S+ITS2 region from closely related acanthocephalans were determined by BLASTn search and downloaded for further analysis.

Multiple sequences alignment was performed using ClustalW as implemented in MEGA v. 6.0 [36] together with other species of acanthocephalans. Phylogenetic analyses were conducted using MEGA v. 6.0 [36] with 1000 bootstrap replicates for prior testing of reliability and Bayesian inference (BI) analyses in Topali 2.5 [31]. For nucleotide alignment of $18 \mathrm{~S}$ and the ITS1+5.8S+ITS2 region, a phylogenetic tree was constructed using the maximum likelihood (ML) method in MEGA v. 6.0. Pairwise distance analyses were carried out using the Maximum Composite Likelihood model [36]. For Bayesian inference (BI) analyses, the substitution models were tested by the Bayesian Information Criterion and GTR+G+I was chosen. Posterior probabilities were estimated over 1,000,000 generations via five independent runs of four simultaneous MCMCMC chains with every 100th tree saved. The "burn in" was set to $25 \%$.

\section{Results}

\section{Neoechinorhynchus (Neoechinorhynchus) johnii Yamaguti, 1939}

Family: Neoechinorhynchidae

Genus: Neoechinorhynchus

Subgenus: Neoechinorhynchus
Hosts, localities, and dates: See Table 1.

Site of infection: Intestine.

Specimens: HWML collection Nos. 139459, 139460, 139465, 139466, 139468 (from J. carouna), 139461, 139463, 139464 (from E. tetradactylum), 139462, 139467 (from O. ruber).

Representative DNA sequences: The 18S and ITS1-5.8SITS2 region of rDNA sequences of $N$. johnii were deposited in GenBank under the accession numbers MK260005 and MK260007 (for the 18S gene), and MK260006 and MK260008 (for the ITS region).

\section{Morphological description}

General. Neoechinorhynchidae. With characters of the genus Neoechinorhynchus and the subgenus Neoechinorhynchus as described by Amin [2]. With prominent sexual dimorphism in size of shared structures. Trunk elongate, cylindrical and slender, slightly but decidedly wider anteriorly. Body wall with osmiophilic micropores throughout (Figs. 6 and 7), often with paired cuticular folds and occasionally with dorsal hump (Fig. 13). Giant hypodermal nuclei not readily observed. Proboscis rounded but slightly wider than long (Fig. 1); with prominent nucleated apical organ. Anterior hooks long with shorter posteriorly directed spoon shaped roots, at apical end of proboscis (Figs. 2 and 14). Middle and posterior hooks small, almost equal, with short stout roots, close together and distant from anterior hooks. Middle hooks, near posterior end of proboscis; posterior hooks slightly smaller, at the attenuated posterior end of proboscis (Fig. 3). Hooks with thin cortical layer and solid but vacuolated core (Figs. 4 and 5). Neck prominent, longer than proboscis, wider at base (Figs. 1 and 15). Proboscis receptacle more than twice as long as proboscis, with ovoid cephalic ganglion at its base and para-receptacle structure (PRS) at least on one side (Fig. 15, arrow). Lemnisci long, slightly sub-equal, with two prominent ovoid giant nuclei each. Gonopore terminal in males and subterminal in females (Figs. 17 and 18).

Males (based on 11 adult specimens from 4 species of fish). See Tables 2 and 3 for measurements. Reproductive system in posterior half of trunk with two long tubular contiguous testes filling width of body cavity. Posterior testis longer than anterior testis. Syncytial cement gland distant from posterior testis; with many linearly arranged large spherical nuclei. Cement reservoir prominent, bulky, elongate, at posterior end of cement gland followed posteriorly by large triangular sperm vesicle, broadest anteriorly, overlapping Saefftigen's pouch. Bursa without prominent ornamentation or marked sensory structures (Fig. 9). 

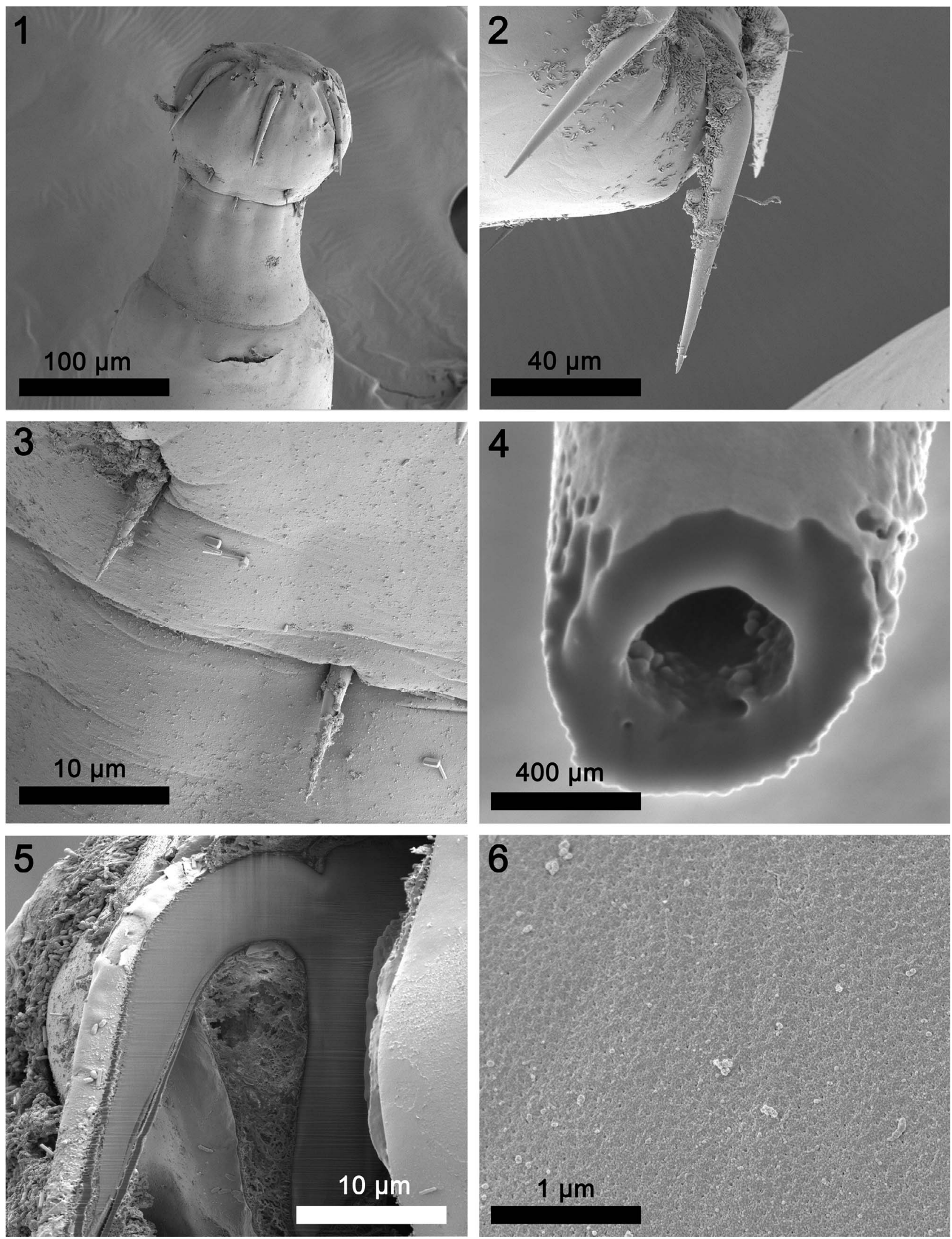

Figures 1-6. SEM of specimens of Neoechinorhynchus johnii from Eleutheronema tetradactylus, Johnius carouna, and Otolithes ruber in the Pacific Ocean off Vietnam. (1) The proboscis and neck of a male specimen. (2) Two anterior proboscis hooks of another specimen. Note the curvature at the base of the otherwise straight hook. (3) Middle and posterior hooks in the proboscis in Figure 1. Note the location of the posterior hook at the furrow separating the proboscis from the neck. (4) A gallium cut cross-section of a hook showing its vacuolated hollow core. (5) A gallium cut longitudinal section near the edge of an anterior hook showing the distinction between the thin cortical layer and the dense core. Note the prominent posteriorly directed root and the slightly manubriated anterior end. (6) Micropores at the mid trunk of a male specimen. 

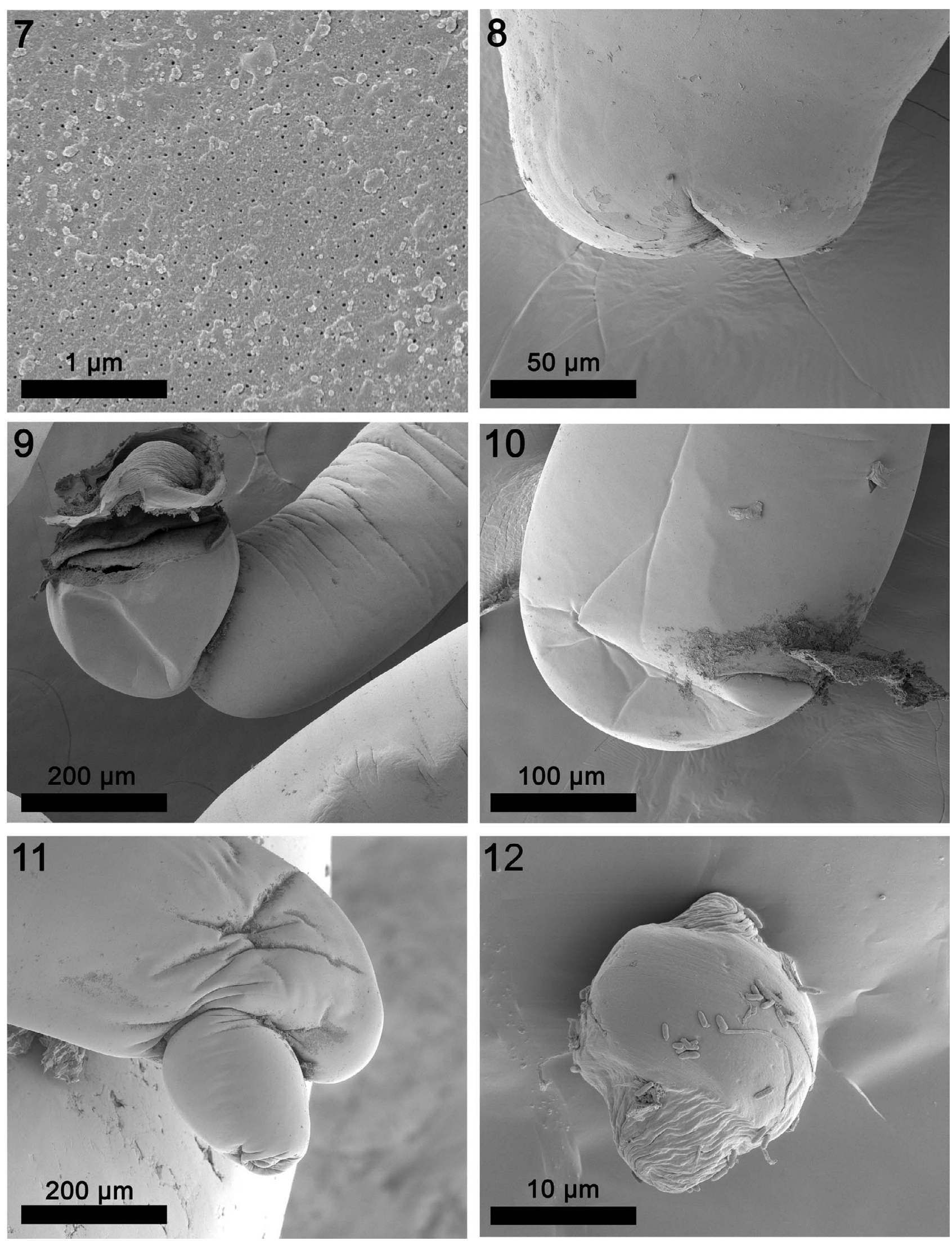

Figures 7-12. SEM of specimens of Neoechinorhynchus johnii from Eleutheronema tetradactylus, Johnius carouna, and Otolithes ruber in the Pacific Ocean off Vietnam. (7) Micropores at the posterior trunk of the same male specimen in Figure 6. Note the different pore diameter and distribution indicative of differential nutrient absorption of different parts of the trunk. (8) The posterior end of a male specimen showing the site of the invaginated bursa. (9) The plain evaginated bursa tilting ventral at the posterior end of a male specimen. (10) Normal rounded outline of the posterior end of a female specimen. (11) A constriction occasionally seen at the posterior end of female specimens contains the looped posterior end of the reproductive system. (12) An egg of the lantern-like variety with fibrous elements. 
13
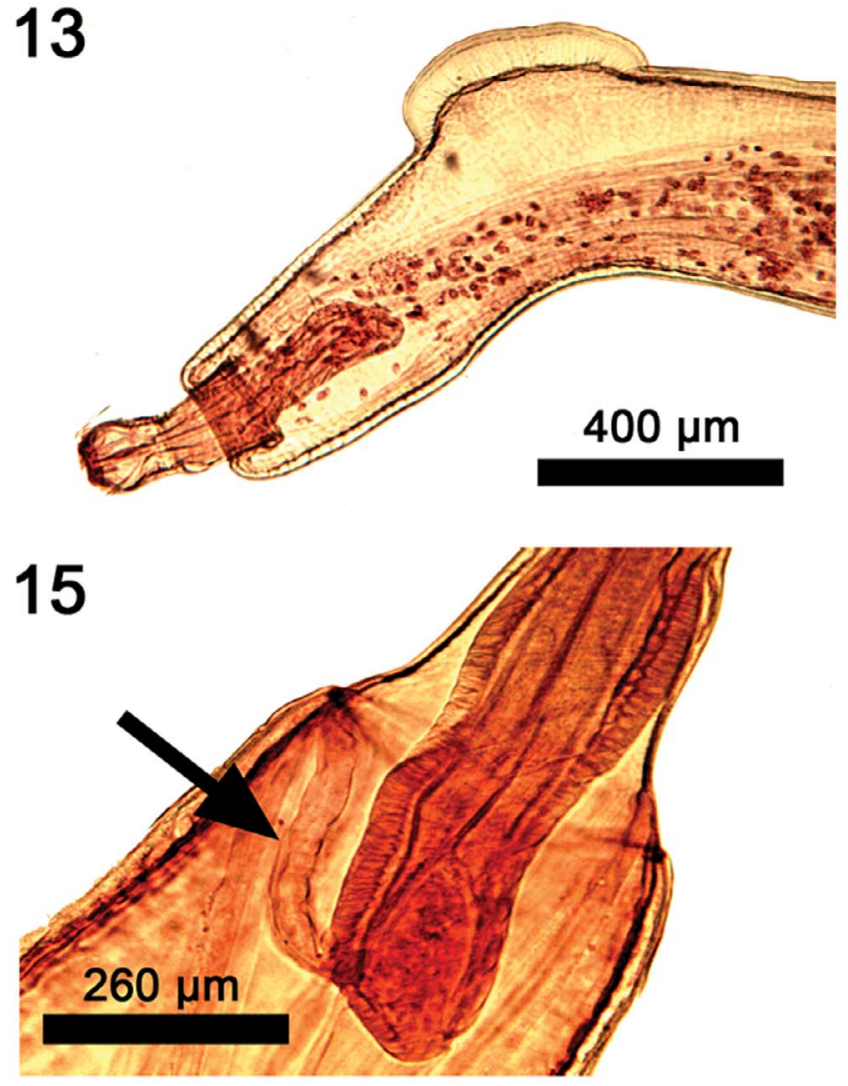

\section{7

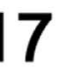

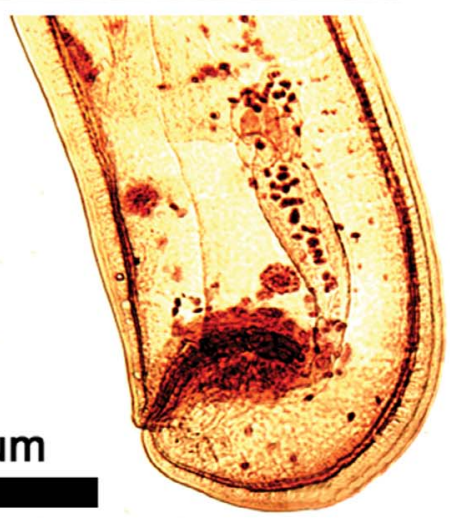

14

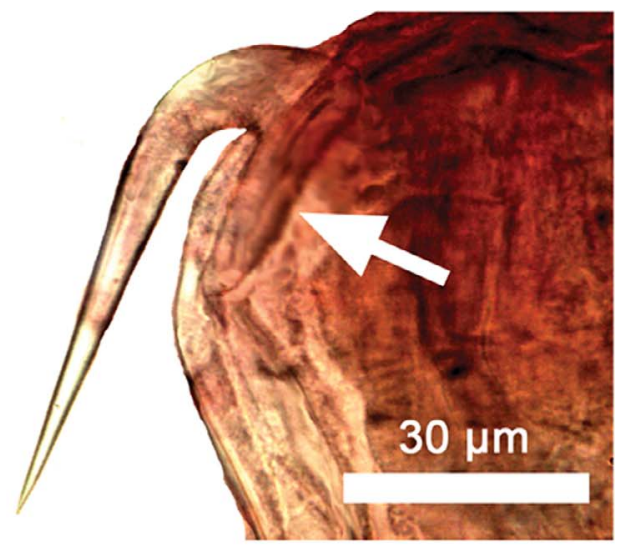

\section{6}
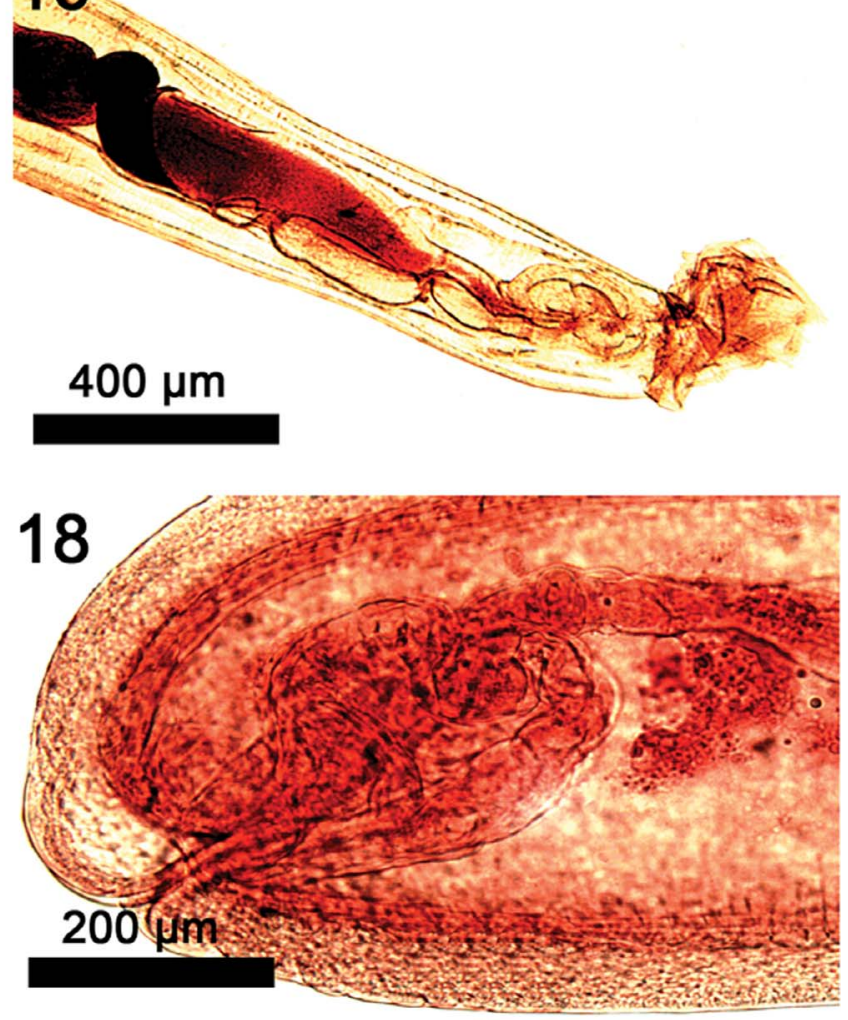

\section{9}
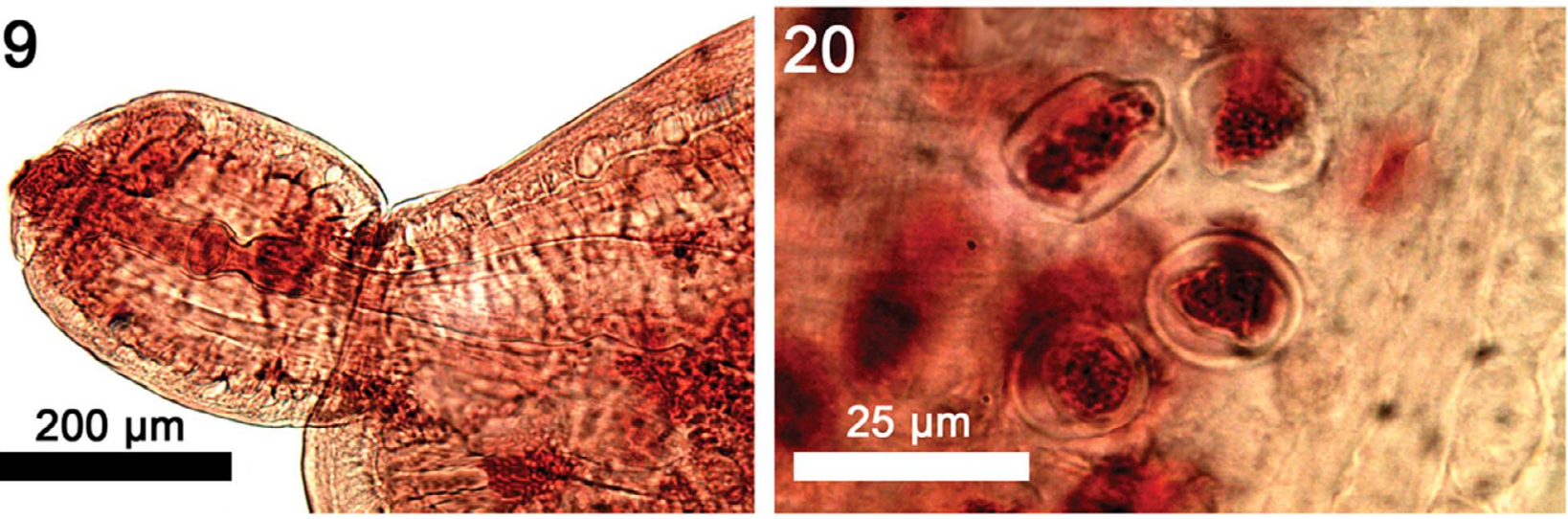

Figures 13-20. Microscopic images of specimens of Neoechinorhynchus johnii from Eleutheronema tetradactylus, Johnius carouna, and Otolithes ruber in the Pacific Ocean off Vietnam. (13) The anterior end of a male specimen showing the typical dorsal curvature and humping. (14) The anterior proboscis showing its characteristic curvature at the base and the prominent posteriorly directed root (arrow). (15) An anterior trunk section showing the para-receptacle structure (arrow) penetrating into the posterior receptacle wall near the large cephalic ganglion. (16) The male reproductive system of a young specimen. (17) The posterior end of a female reproductive system with a typical expanded curved vagina and a subventral gonopore. (18) Another typically convoluted posterior end of a female reproductive system. (19) An image showing an often-observed constriction at the posterior tip of a female trunk. (20) A rare image of the two types of eggs in the same frame, the spheroid egg and the lantern-like egg. 
Table 2. Morphometric comparisons between our specimens of Neoechinorhyhchus johnii from Vietnam and those reported in previous descriptions from Japan and the Indian Ocean.

\begin{tabular}{|c|c|c|c|c|}
\hline Characters & $\begin{array}{l}\text { Yamaguti (1939) } \\
\text { East China Sea }\end{array}$ & $\begin{array}{c}\text { Bilqees }(1972) \\
\text { Karachi coast, Pakistan }\end{array}$ & $\begin{array}{l}\text { Gupta and Jain (1983) } \\
\text { off Panaji, Bombay, India }\end{array}$ & $\begin{array}{c}\text { Present paper } \\
\text { Pacific Ocean off Vietnam }\end{array}$ \\
\hline Hosts & Johnius goma & Pseudosciaena diacanthus & Pseudosciaena diacanthus & $\begin{array}{c}\text { Eleutheronema tetradactylum, Otolithes ruber, } \\
\text { Johnius carouna, Johnius sp. }\end{array}$ \\
\hline Specimens described & 4 females & 1 male, 4 females & 6 of 51 males, 0 of 35 females & 11 males, 32 females \\
\hline \multicolumn{5}{|l|}{ Males } \\
\hline Trunk $L \times W(\mathrm{~mm})$ & $\overline{-}$ & $2.8 \times 0.08$ & $21.71-26.97 \times 0.55-0.65$ & $13.35-35.00(25.26) \times 0.35-0.75(0.51)^{*}$ \\
\hline Proboscis $L \times W$ & 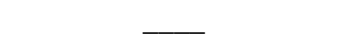 & $80 \times 80$ & $101-142 \times 129-191$ & $120-157(136) \times 150-167(146)$ \\
\hline Hook from ant. & $\ldots$ & $100,30-40,17-20$ & $89-93,20-24,20-24$ & 67-112 (93), 25-30 (27), 22-27 (25) \\
\hline Neck $L \times W$ & $\ldots$ & & $142-211 \times 146-215$ & $114-281(207) \times 146-279(204)$ \\
\hline Prob. Receptacle $L \times W$ & $\ldots$ & $170 \times$ & $406-536 \times 130-163$ & $300-572(432) \times 92-166(135)$ \\
\hline Long lemniscus $L \times W$ & 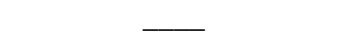 & ca. 1.00 & $1.82-2.92 \times 0.08-0.11$ & $2.24-3.12(2.51) \times 0.06-0.10(0.08)$ \\
\hline Short lemniscus $L \times W$ & & ca. 1.00 & $1.82-2.92 \times 0.08-0.11$ & $2.27-3.12(2.41) \times 0.06-0.10(0.07)$ \\
\hline Ant. Testis $L \times W(\mathrm{~mm})$ & & Ovate $0.13 \times 0.10$ & $1.95-3.44 \times 0.23-0.44$ & $2.75-8.12(4.80) \times 0.17-0.50(0.32)$ \\
\hline Post. Testis $L \times W(\mathrm{~mm})$ & & Tubular $1.89 \times 0.05$ & $2.11-4.27 \times 0.21-0.42$ & $3.00-10.00(5.75) \times 0.20-0.62(0.32)$ \\
\hline Cement gland $L \times W(\mathrm{~mm})$ & 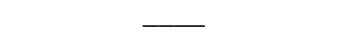 & $1.51 \times 0.02$ & $3.22-4.83 \times 0.19-0.34$ & $1.15-4.87(3.01) \times 0.12-0.34(0.21)$ \\
\hline Cement gland nuclei & . & - & $12-13$ & $16-25(20.3)$ \\
\hline Cement reservoir $L \times W$ & 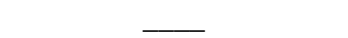 & $310 \times 50$ & $406-504 \times 195-293$ & $364-624(416) \times 104-281(187)$ \\
\hline Sperm vesicle $L \times W$ & 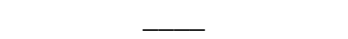 & $250 \times 50$ & $525-1008 \times 146-228$ & $520-1144(888) \times 94-250(177)$ \\
\hline Saefftigen's pouch $L \times W$ & ב & $\ldots$ & $601-780 \times 81-146$ & 593-936 (749) × 84-208 (146) \\
\hline Bursa $L \times W$ & 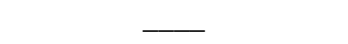 & Papillated $50 \times 100$ & $325-861 \times 162-552$ & $364-624(489) \times 353-676(469)$ \\
\hline \multicolumn{5}{|l|}{ Females } \\
\hline Trunk $L \times W(\mathrm{~mm})$ & $40.00-63.00 \times 0.95-1.10$ & $45.00-61.00 \times 0.70-1.13$ & _ & $10.00-120.00(44.75) \times 0.27-1.17(0.64)$ \\
\hline Proboscis $L \times W$ & $\times 110-120$ & $80-160 \times 90-160$ & & $112-187(154) \times 120-182(159)$ \\
\hline Hook from ant. & $90-100,21-24,21-24$ & $80-90,50-60,19-20$ & & $62-117$ (102), 25-31 (27), 22-30 (26) \\
\hline Neck $L \times W$ & $170-250 \times 110-130$ & 208-302 (246) × 146-281 (196) & & \\
\hline Prob. Receptacle $L \times W$ & $400-520 \times 90-140$ & $38 \times$ & - & 255-551 (466) × 87-177 (129) \\
\hline Long lemniscus $L \times W$ & $2.50-3.80 \times 0.10-0.11$ & $2.70-3.30 \times$ & & $2.39-3.33(2.87) \times 0.006-0.18(0.09)$ \\
\hline Short lemniscus $L \times W$ & $2.50-3.80 \times 0.10-0.11$ & $2.70-3.30 \times$ & 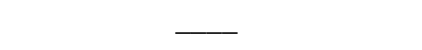 & $2.39-3.17(2.73) \times 0.06-0.15(0.08)$ \\
\hline Vagina length & & $200-250$ & 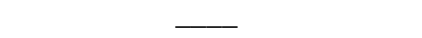 & $156-260(209)$ \\
\hline Uterus length & $250-480 \times 80-125$ & $300-400$ & 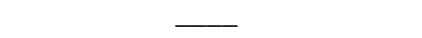 & $250-572(454)$ \\
\hline Uterine bell length & - & $140-170 \times 100-160$ & $\ldots$ & $250-624(477)$ \\
\hline Reprod. syst. $L(\mathrm{~mm})$ & - & - & & $0.67-1.51(1.13)$ \\
\hline Egg $L \times W$ & $33 \times 18$ & $29-30 \times 20$ & $33-38 \times 20-22$ & $27-45(33) \times 18-30(24)$ \\
\hline
\end{tabular}

${ }^{*}$ Range (mean). 
Table 3. The relationship between host species and size of certain anatomical structures of 43 measured specimens of Neoechinorhynchus johnii collected off the Pacific coast of Vietnam mostly in 2017.

\begin{tabular}{lcccc}
\hline Worm sex & Character & \multicolumn{3}{c}{ Host species } \\
\cline { 3 - 5 } & & Eleutheronema tetradactylum $(n=13)$ & Johnius carouna $(n=22)$ & Otolithes ruber $(n=8)$ \\
\hline Female & Trunk length $(\mathrm{mm})$ & $15.0-120.00(62.58)^{*}$ & $10.00-46.25(31.77)$ & $50.00-61.00(55.00)$ \\
Male & Trunk length $(\mathrm{mm})$ & 25.60 & $13.75-27.50(22.50)$ & $30.00-35.00(32.00)$ \\
Female & Proboscis length & $112-145(131)$ & $142-162(151)$ & $160-187(169)$ \\
Female & Ant. Proboscis hook $L$ & $62-100(83)$ & $97-117(107)$ & $97-112(109)$ \\
Male & Ant. Proboscis hook $L$ & $62-67(64)$ & $92-112(104)$ & 107 \\
Female & Prob. Receptacle $L$ & $255-468(380)$ & $400-551(475)$ & $510-551(530)$ \\
Male & Prob. Receptacle $L$ & 343 & $300-468(401)$ & 572 \\
Male & Post. Testis $L(\mathrm{~mm})$ & 4.25 & $3.00-10.00(5.25)$ & $8.12-8.95(8.53)$ \\
\hline
\end{tabular}

* Range (mean).

Females (based on 32 adults with eggs and ovarian balls from 4 species of fish). See Tables 2 and 3 for measurements. Reproductive system with prominent vaginal sphincter, bulb and tube, thick-walled fusiform uterus, few large uterine glands of selector apparatus, and large conical uterine bell attached to body wall ventrally. Adults with introverted genital vestibule lined with invaginated body wall (Figs. 17 and 18) but occasionally adults and immatures with terminal or subterminal digitiform prolongation of posterior trunk tip with terminal gonopore (Figs. 11 and 19). Eggs either spherical and thick walled showing no prolongation of fertilization membrane or more rectangular with soft corners and two cone-shaped poles (Figs. 12 and 20).

\section{Relationships to host species}

The measurements provided for specimens of $N$. johnii collected from four species of fish (Table 2) demonstrate considerable variability in the size of certain structures that appear to be associated with host species (Table 3). Most noticeably, the longest worms from E. tetradactylum (females reaching 120.0 $\mathrm{mm}$ in length) had the shortest anterior proboscis hooks in males and females averaging 64-83 long compared to anterior hooks of worms from $J$. carouna and $O$. ruber that exceeded 100 in length. Size of the proboscis, proboscis receptacle, and testes was similarly smaller in worms obtained from
E. tetradactylum compared with worms from J. carouna and O. ruber.

\section{Remarks}

We have provided the morphological description of 11 male and 32 female specimens of $N$. johnii from 20 and 40 specimens obtained from four new species of fish collected along the Pacific coast of Vietnam (Table 1). The previous three descriptions were incomplete and inadequate. Yamaguti [40] originally described the species from four females with two line drawings (his Figs. 37 and 38) collected from Johnius goma (Tanaka) in the East China Sea. Bilqees [21] described one $2.8 \mathrm{~mm}$ long male of uncertain identity with ovate anterior testis and four females with line drawings (her Figs. 9-16) from Pseudosciaena diacanthus Lacepède off the Karachi coast of Pakistan. Gupta and Jain [25] described only six males from $D$. diacanthus also in the Indian Ocean off Panaji and Bombay, India, even though they collected 51 males and 35 females but provided line drawings of both males and females (their Fig. 2a-h). Bilqees [21] reported unusually large middle proboscis hooks, two or three times as large as the posterior hooks, which is a serious departure from the original description of the species where middle and posterior hooks have the same size. Gupta and Jain [25] mentioned egg size in females that were not described. The size of most structures of the single diminutive male from Pakistan

Table 4. Chemical composition of a Gallium (Ga, LMIS) cut of anterior hook of Neoechinorhynchus johnii.

\begin{tabular}{|c|c|c|c|c|c|c|}
\hline \multirow[t]{2}{*}{ Element*** } & \multicolumn{2}{|c|}{ Hook tip* } & \multicolumn{2}{|c|}{ Hook middle* } & \multicolumn{2}{|c|}{ Base of hook** } \\
\hline & Edge & Center & Edge & Center & Arch & Bottom \\
\hline Magnesium (Mg) & 0.07 & 1.25 & 0.57 & 2.21 & $1.83 * * * *$ & 2.05 \\
\hline Phosphorous (P) & 1.62 & 10.69 & 3.62 & 14.32 & 14.55 & 15.51 \\
\hline Sulphur (S) & 15.57 & 5.14 & 11.73 & 0.61 & 0.22 & 0.23 \\
\hline Calcium (Ca) & 2.36 & 19.84 & 4.66 & 26.79 & 27.56 & 31.12 \\
\hline
\end{tabular}

* Cross section cut.

** Longitudinal cut.

**** Common protoplasmic elements $(\mathrm{C}, \mathrm{N}, \mathrm{O})$ and processing elements (Au, Pd, Ga) omitted from table. Listed in wt\%.

***** Bold weight \% figures are used to generate the spectrum (Fig. 21). 


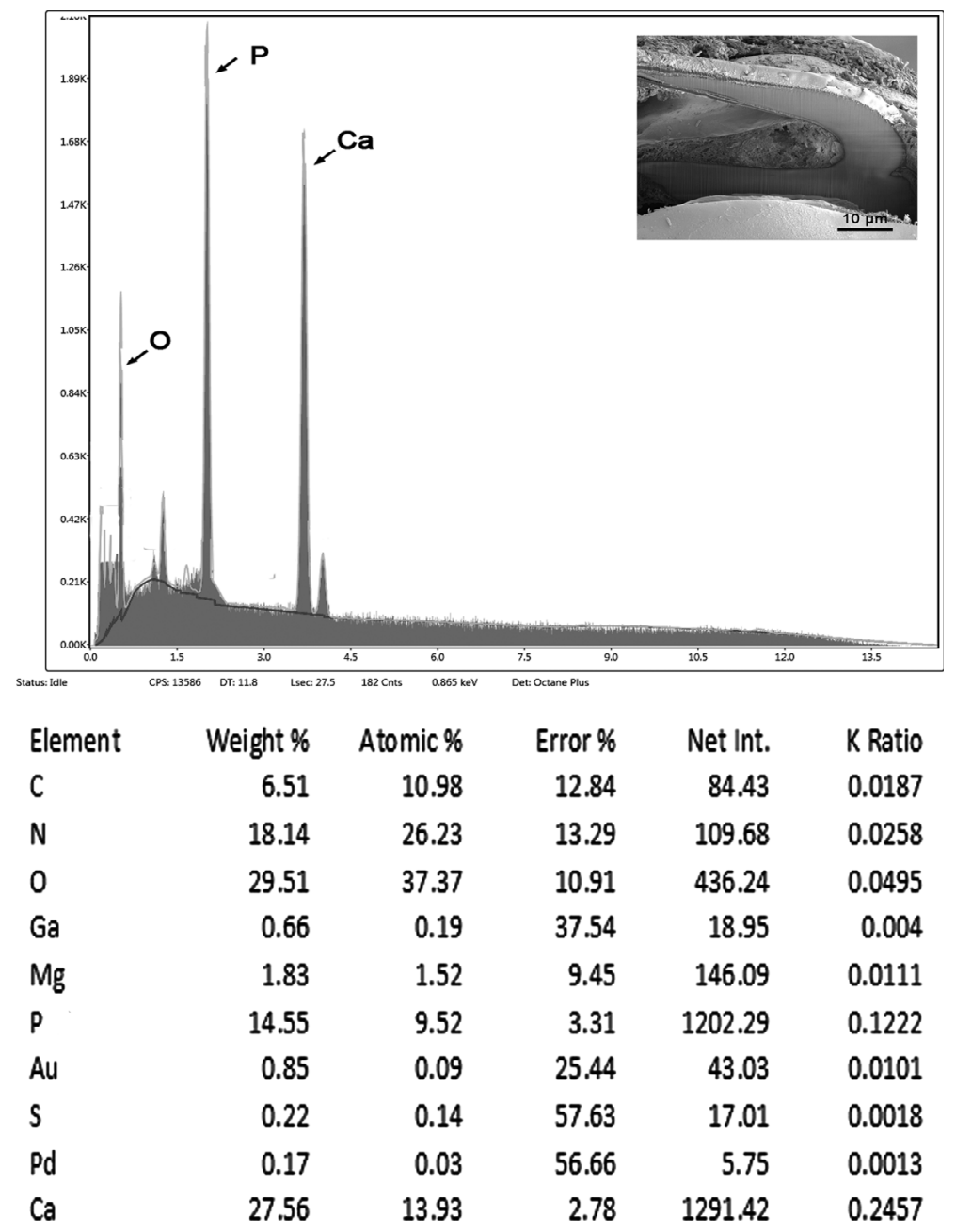

Figure 21. Energy Dispersive X-Ray spectrum of the base center of a large hook of a Neoechinorhynchus johnii specimen showing high levels of calcium and phosphorus (see Table 4). Insert: SEM of a lateral longitudinal gallium cut hook. The X-ray data are the elemental analysis of the hook base.

[21] could not be objectively compared to that of corresponding structures from the six males from India [25] collected from the same host species, $P$. diacanthus, to examine the influence of host species. Comparative measurements in Table 2 show that our specimens from four host species in Vietnam collectively had the largest size of trunk, proboscis, proboscis hooks, neck, and testes, and more cement gland nuclei. When those measurements were broken down by host species (Table 3), the relationship of host species to the size of taxonomically important structures such as trunk, anterior proboscis hooks, proboscis and testes became quite apparent.

We consider the line drawings of the above authors sufficient to give a sense of the morphology of $N$. johnii and we provide additional insights and new information of various anatomical structures of this species using photo-microscopy (Figs. 13-20) and SEM (Figs. 1-12) of our specimens collected off the Pacific coast of Vietnam (Table 1). Our Vietnamese hosts are of Indo-West Pacific distribution extending between India and east Africa to the west and the Gulf of Thailand, southern China, and the West Pacific to the east [32, 35]. Our findings provide the first complete description of this species and show considerable variations between our Vietnamese specimens and those reported by other authors (Table 2). Our findings also demonstrate the relationships between size of certain structures and host species (Table 3 ).

\section{EDAX findings}

Table 4 and Figure 21 show the results of the hook chemical element analysis. Chemical elements observed were typical for acanthocephalan hooks with high sulfur content on the outer edge of the hook and increased amounts of calcium and phosphorus in the center areas. Both cross-section cuts and longitudinal cuts were analyzed.

\section{Molecular description}

In this study, we compared DNA sequences of $N$. johnii species from Vietnam with sequences of the closely related species of the same genus, Neoechinorhynchus, and other acanthocephalans retrieved from GenBank (Tables 5 and 6). For the analysis, we choose the $18 \mathrm{~S}$ gene as it is highly conserved and better for an analysis of the upper level phylogeny, while 
Table 5. Acanthocephala species, origin and GenBank accession numbers used for phylogenetic analysis based on the $18 \mathrm{~S}$ region. Sequences marked with an asterisk were obtained in this study. $\mathrm{Na}=$ not available.

\begin{tabular}{|c|c|c|c|}
\hline Species & Host & Host origin & GenBank accession no. \\
\hline \multicolumn{4}{|c|}{ Neoechinorhynchus Stiles and Hassall 1905} \\
\hline Neoechinorhynchus tumidus & Coregonus nasus & Russia & KF156876 \\
\hline Neoechinorhynchus simansularis & Salvelinus alpinus & Russia & KF156877 \\
\hline Neoechinorhynchus salmonis & Onchorynchus nerka & Russia & KF156878 \\
\hline Neoechinorhynchus saginata & $\mathrm{Na}$ & USA & AY830150 \\
\hline Neoechinorhynchus beringianus & Pungitius pungitius & Russia & KF156875 \\
\hline Neoechinorhynchus pseudemydis & Capoeta aculeata & Iran & KU363973 \\
\hline Neoechinorhynchus pseudemydis & $\mathrm{Na}$ & USA & NPU41400 \\
\hline Neoechinorhynchus crassus & $\mathrm{Na}$ & Iran & KU363969 \\
\hline Neoechinorhynchus crassus & $\mathrm{Na}$ & USA & AF001842 \\
\hline Neoechinorhynchus sp. & $\mathrm{Na}$ & China & KM507363 \\
\hline Neoechinorhynchus sp. & Capoeta aculeata & Iran & KU363972 \\
\hline Neoechinorhynchus saginata & $\mathrm{Na}$ & Iran & KU363970 \\
\hline Neoechinorhynchus crassus & Capoeta aculeata & Iran & KU363974 \\
\hline Neoechinorhynchus crassus & Capoeta aculeata & Iran & KU363971 \\
\hline Neoechinorhynchus sp. & Siganus fuscescens & China & HM545898 \\
\hline Neoechinorhynchus buttnerae & $\mathrm{Na}$ & Brazil & MK249749 \\
\hline Neoechinorhynchus cylindratus & Micropterus salmoides & USA & MF974925 \\
\hline Neoechinorhynchus johnii & Eleutheronema tetradactylus & Vietnam & MK260005* \\
\hline Neoechinorhynchus johnii & Johnius carouna & Vietnam & MK260007* \\
\hline Neoechinorhynchus sp. & Siganus fuscescens & China & HM545897 \\
\hline Neoechinorhynchus sp. & Heteropneustes fossilis & India & MF784256 \\
\hline Neoechinorhynchus sp. & Oreochromis niloticus & Democratic Republic of the Congo & DQ181946 \\
\hline \multicolumn{4}{|l|}{ Pallisentis Van Cleave 1928} \\
\hline Pallisentis sp. 1 & $\mathrm{Na}$ & India & KY491740 \\
\hline Pallisentis sp. 4 & $\mathrm{Na}$ & India & KY305516 \\
\hline Pallisentis sp. 5 & $\mathrm{Na}$ & India & KY305517 \\
\hline Pallisentis sp. 6 & $\mathrm{Na}$ & India & KY305518 \\
\hline Pallisentis sp. 7 & $\mathrm{Na}$ & India & KY305519 \\
\hline Pallisentis sp. 9 & $\mathrm{Na}$ & India & KY305521 \\
\hline Pallisentis sp. 10 & $\mathrm{Na}$ & India & KY305522 \\
\hline \multicolumn{4}{|l|}{ Acanthosentis Verma and Datta 1929} \\
\hline Acanthosentis sp. 1 & $\mathrm{Na}$ & India & KY305529 \\
\hline Acanthosentis sp. 2 & $\mathrm{Na}$ & India & KY305530 \\
\hline \multicolumn{4}{|l|}{ Floridosentis Ward 1953} \\
\hline Floridosentis mugilis & Mugil cephalus & Mexico & AF064811 \\
\hline \multicolumn{4}{|l|}{ Hebesoma Van Cleave 1928} \\
\hline Hebesoma violentum & Perccottus glenii & Russia & KF156881 \\
\hline \multicolumn{4}{|c|}{ Echinorhynchidae (Ward, 1917) Van Cleave, 1928} \\
\hline Echinorhynchida sp. & Cichlasoma urophthalmus & Mexico & EU732662 \\
\hline \multicolumn{4}{|l|}{ Leptorhynchoides Kostylev 1924} \\
\hline Leptorhynchoides thecatus & Lepomis cyanellus & USA & AF001840 \\
\hline \multicolumn{4}{|l|}{ Outgroup } \\
\hline Moniliformis moniliformis & $\mathrm{Na}$ & UK & Z19562 \\
\hline Macracanthorhynchus hirudinaceus & Sus scrofa leucomystax & Japan & LC350002 \\
\hline Mediorhynchus sp. & Casidix mexicanus & Mexico & AF064816 \\
\hline
\end{tabular}

the ITS1-5.8S-ITS2 region is additionally beneficial to differentiate between species. DNA fragments of the $18 \mathrm{~S}$ and ITS15.8S-ITS2 datasets were sequenced for individuals of $N$. johnii. Our sequences from two isolates from two different hosts of $N$. johnii for $18 \mathrm{~S}$ and the ITS1+5.8S+ITS2 region show no detectable intraspecific sequence variability among the individuals sampled. Isolates from all host species were not possible because of limited sample sizes. The genetic divergence estimated among the species of Neoechinorhynchus used for phylogenetic analysis (Table 5 and 6) ranged from 0.06 to $0.28 \%$ for $18 \mathrm{~S}$ and from 0.15 to $0.24 \%$ for the ITS1-5.8S-ITS2 region, respectively. For the $18 \mathrm{~S}$ gene, both $\mathrm{ML}$ and $\mathrm{BI}$ analyses recovered the newly generated sequence for $N$. johnii from Vietnam and formed a strongly supported individual sister clade (100/1.00). The isolate of $N$. johnii obtained demonstrated the association with Neoechinorhynchus salmonis Ching, 1984 (KF156878) from Lake Chistoe, Russia. Both the species show $92.86 \%$ identity along with other species of Neoechinorhynchus from a clade belonging to Mexico, China, Iran, Russia and the USA (Fig. 22). For the ITS1+5.8S+ITS2 sequence dataset, the phylogenetic analyses resulting from both ML and BI analyses were highly congruent. Newly generated sequences for N. johnii clustered together with the sequences of $N$. roseum SalgadoMaldonado, 1978 (FJ388981) from Mexico were strongly 
Table 6. Acanthocephala species, origin and GenBank accession numbers used for phylogenetic analysis based on the ITS1-5.8S-ITS2 gene cluster. Sequences marked with an asterisk were obtained in this study. $\mathrm{Na}=$ not available.

\begin{tabular}{|c|c|c|c|}
\hline Species & Host & Host origin & GenBank accession no. \\
\hline \multicolumn{4}{|c|}{ Neoechinorhynchus Stiles and Hassall 1905} \\
\hline Neoechinorhynchus sp. & Dormitator latifrons & Mexico & MG870633 \\
\hline Neoechinorhynchus sp. & Dormitator latifrons & Mexico & MG870632 \\
\hline Neoechinorhynchus sp. & Dormitator latifrons & Mexico & MG870630 \\
\hline Neoechinorhynchus sp. & Dormitator latifrons & Mexico & MG870631 \\
\hline Neoechinorhynchus sp. & Dormitator latifrons & Mexico & MG870626 \\
\hline Neoechinorhynchus sp. & Dormitator latifrons & Mexico & MG870627 \\
\hline Neoechinorhynchus sp. & Dormitator latifrons & Mexico & MG870628 \\
\hline Neoechinorhynchus sp. & Dormitator latifrons & Mexico & MG870629 \\
\hline Neoechinorhynchus mamesi & Dormitator latifrons & Mexico & MG870870 \\
\hline Neoechinorhynchus sp. & $\mathrm{Na}$ & Mexico & KY077110 \\
\hline Neoechinorhynchus sp. & $\mathrm{Na}$ & Mexico & KY077111 \\
\hline Neoechinorhynchus roseum & Citharichthys gilbertei & Mexico & FJ388981 \\
\hline Neoechinorhynchus mamesi & Dormitator latifrons & Mexico & MG870869 \\
\hline Neoechinorhynchus chimalapasensis & Awaous banana & Mexico & MG870865 \\
\hline Neoechinorhynchus chimalapasensis & Awaous banana & Mexico & MG870864 \\
\hline Neoechinorhynchus johnii & Eleutheronema tetradactylum & Vietnam & MK260008* \\
\hline Neoechinorhynchus johnii & Johnius carouna & Vietnam & MK260006* \\
\hline Neoechinorhynchus schmidti & Trachemys scripta & Mexico & MG870837 \\
\hline Neoechinorhynchus schmidti & Trachemys scripta & Mexico & MG870836 \\
\hline Neoechinorhynchus emyditoides & Trachemys scripta & Mexico & MG870862 \\
\hline Neoechinorhynchus emyditoides & Trachemys scripta & Mexico & MG870861 \\
\hline Neoechinorhynchus emyditoides & Trachemys scripta & Mexico & MG870854 \\
\hline Neoechinorhynchus mexicoensis & Dormitator maculatus & Mexico & KY077106 \\
\hline Neoechinorhynchus cylindratus & Micropterus salmoides & Mexico & MK089806 \\
\hline Neoechinorhynchus saginatus & NA & Mexico & FJ388984 \\
\hline \multicolumn{4}{|l|}{ Atactorhynchus Chandler 1935} \\
\hline Atactorhynchus duranguensis & Cyprinodon meeki & Mexico & KY077113 \\
\hline \multicolumn{4}{|l|}{ Floridosentis Ward 1953} \\
\hline Floridosentis mugilis & Mugil cephalus & Mexico & KC004179 \\
\hline \multicolumn{4}{|c|}{ Mayarhynchus Pinacho-Pinacho, Hernández-Orts, Sereno-Uribe, Pérez-Ponce de León and García-Varela 2017} \\
\hline Mayarhynchus karlae & Thorichthys ellioti & Mexico & KY077098 \\
\hline \multicolumn{4}{|l|}{ Outgroup } \\
\hline Acanthosentis cheni & Coilia nasus & China & JX960752 \\
\hline
\end{tabular}

associated (98/1.00\%) with other species of Neoechinorhynchus from Mexico (Fig. 23). When the data set consisted of $18 \mathrm{~S}$ and the ITS1-5.8S-ITS2 region used to generate the tree, the tree showed paraphyly of the genus Neoechinorhynchus that can be studied more congruently after addition of other congeneric species data worldwide.

In spite of the increasing number of described species of acanthocephalans from Vietnam, no molecular data are available for species of the genus Neoechinorhynchus to date. Molecular sampling of members of the genus Neoechinorhynchus is still lacking. The 18S and ITS1-5.8-ITS2 datasets included in our study are the only representative sequences for N. johnii to date.

\section{Discussion}

We provide a complete description of $N$. johnii for the first time from four new species of fish off the Vietnam Pacific coast. Our material fills certain serious gaps in knowledge of the species, which was based on previous incomplete and inadequate descriptions. This acanthocephalan species is clearly of
Indo-Pacific distribution and is found in hosts that naturally inhabit waters off the Japanese islands, India and Pakistan. Its distribution in the Pacific waters of Vietnam extended from Tien Yen in the north to Vung Tau, Nha Trang, and Bac Lieu in the south (Table 1). It will not be surprising to find this acanthocephalan from the same host species elsewhere within their endemic range in the Indo-Pacific region.

\section{Variability}

Much of the reported variability in the size of taxonomically important structures such as the trunk, proboscis hooks, proboscis, testes, etc. has been attributed to host species. Such relationships have previously been reported in other species of acanthocephalans including Echinorhynchus salmonis Müller, 1784 in Lake Michigan where male and female specimens from bloater, Coregonus hoyi (Gill) (Salmonidae) achieved not only larger size but also different body form (broad anteriorly) compared to the slender specimens from rainbow smelt, Osmerus mordax (Mitchell) (Osmeridae) [4]. The larger and heavier worms from bloater almost invariably showed higher regression coefficients (adjusted coefficient of determination) compared to 

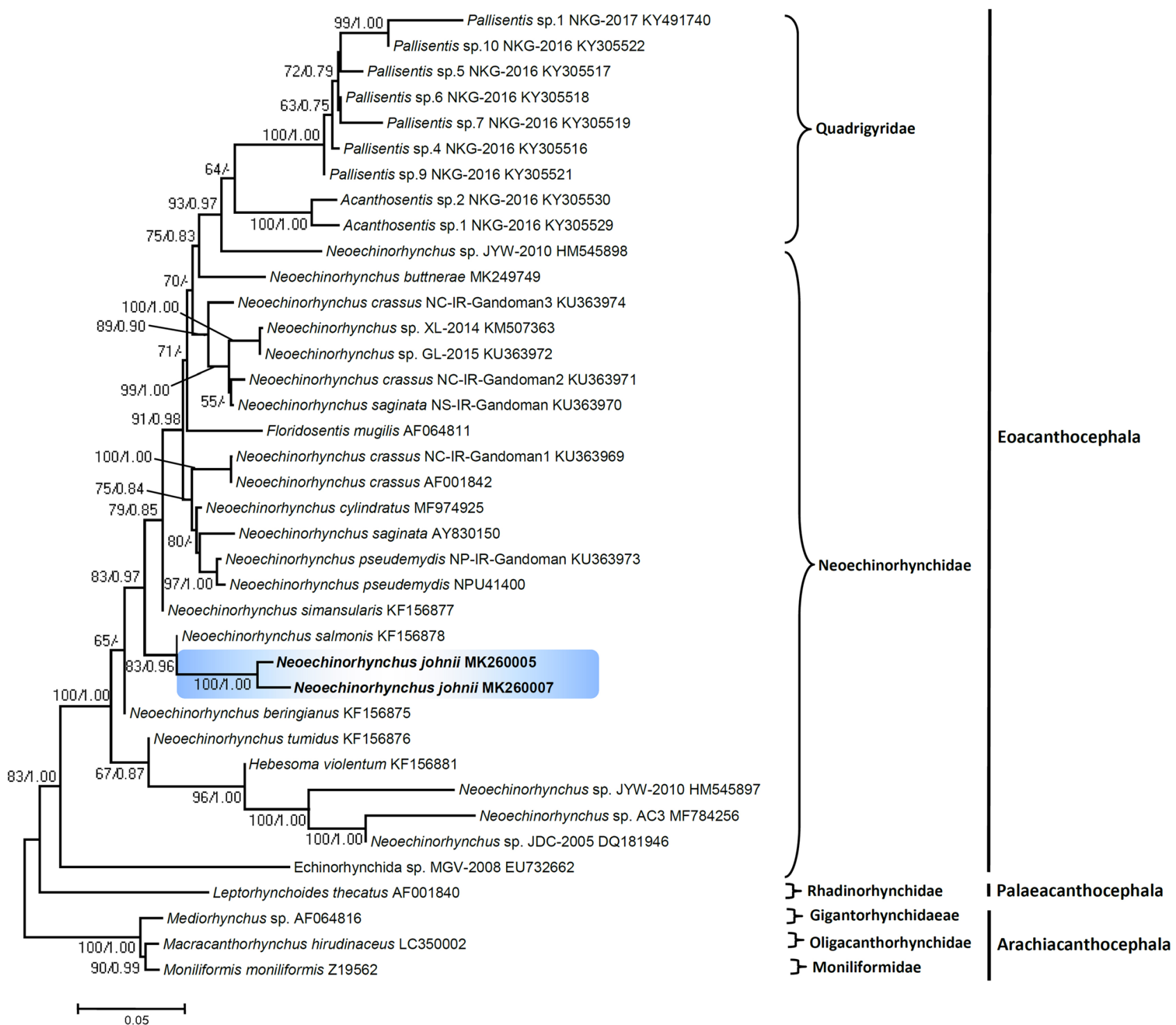

Figure 22. Phylogenetic tree of Neoechinorhynchus johnii species of the nucleotide 18S data set. The bootstrap values are listed in the order: ML/BI. Hyphen indicates a node unsupported by BI. GenBank accession numbers are provided alongside the species names. Species of Archiacanthocephala were selected as the out-group species for the $18 \mathrm{~S}$ gene.

those from smelt in all characters including size of trunk, proboscis, longest proboscis hooks, receptacle, testes, lemnisci, and eggs. The taxonomic implications of this variability were discussed [4], but the reported material from Vietnam remains attributable to $N$. johnii.

Earlier, Amin [1] demonstrated a similar relationship for Acanthocephalus dirus (Van Cleave, 1931) Van Cleave and Townsend, 1936 in Wisconsin fishes. Females of the same developmental stage recovered during the same period were found to have attained larger sizes in certain hosts than in others, with the largest females being found in Lepomis macrochirus Rafinesque. The size of the trunk in males was also found to follow the same pattern. Similarly, testes also attained a larger size in males recovered from Catostomus commersonii Lacépède (Catostomidae) than in males from Semotilus atromaculatus (Mitchill) (Cyprinidae). Amin [1] stated that these size variations "result from differential growth rates of these worms in the various host intestinal environments (and) are probably mediated by certain host specific factors."

\section{The para-receptacle structure (PRS)}

The PRS inserts anteriorly in the body wall near the neck and posteriorly at the posterior end of the receptacle. The presence of the PRS in eoacanthocephalans with a weak single proboscis receptacle wall was first demonstrated in Neoechinorhynchus (N.) qatarensis Amin, Saoud, Alkuwari, 2002 [19] and has since been reported in other species of Neoechinorhynchus and Acanthogyrus (Acanthosentis) Verma and Datta, 1929 reviewed in part in Amin et al. [15] and reported here for the first time in various species of Neoechinorhynchus from marine fishes off the east coast of Vietnam. In the description of the PRS, Amin et al. [7, 19] proposed that 


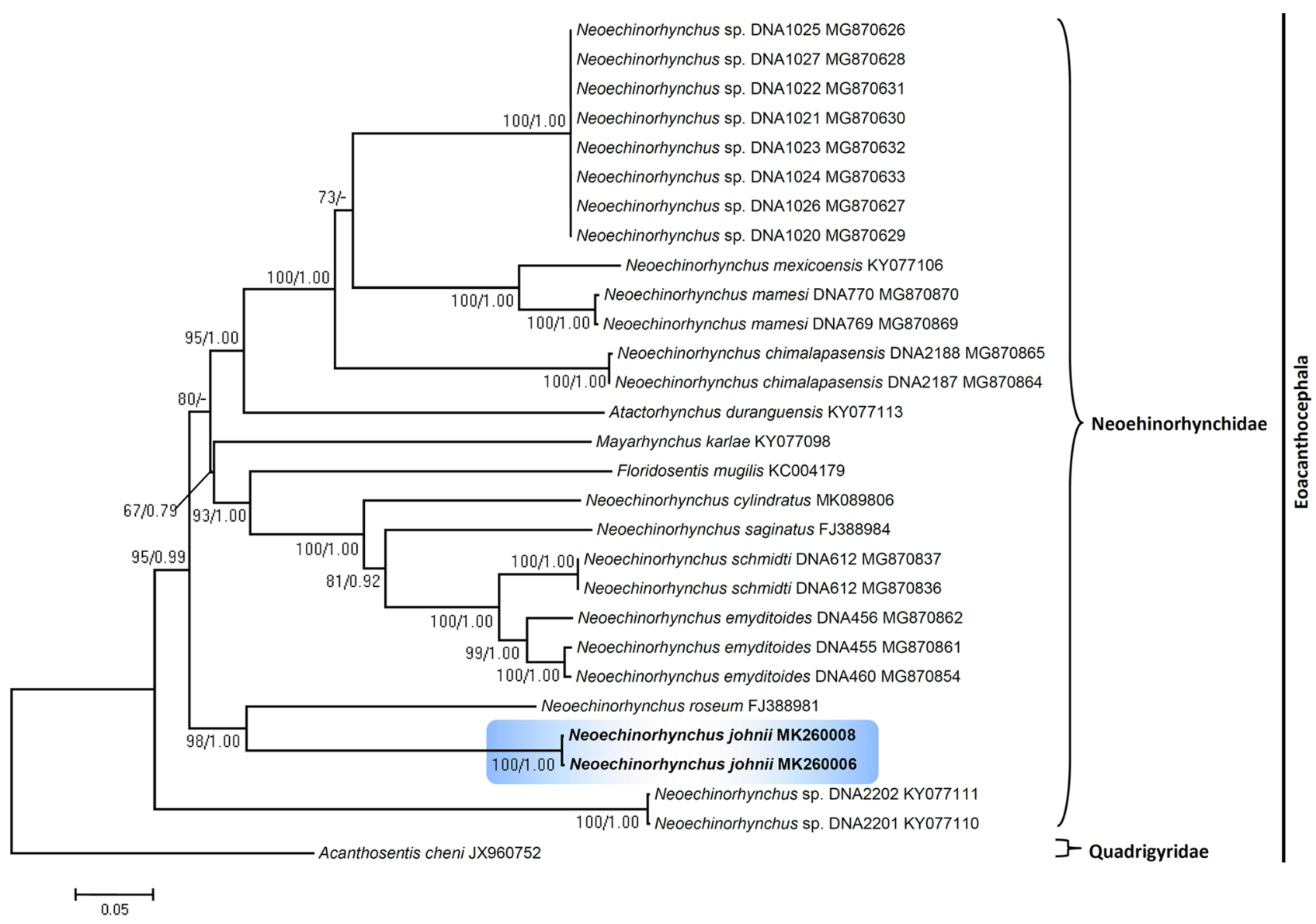

Figure 23. Phylogenetic analysis of the ribosomal ITS1-5.8S-ITS2 region using the maximum likelihood method. Numbers at nodes indicate ML bootstrap values (1000 replications) and posterior probabilities (BI), respectively with GenBank accession numbers listed alongside the species names. Hyphen indicates a node unsupported by BI. Acanthosentis cheni (JX960752) was selected as the out-group species for the ITS1+5.8S+ITS2 region.

it may regulate the hydrostatic pressure in the receptacle to facilitate the retraction and eversion of the proboscis.

\section{Electron dense micropores}

Micropores are present throughout the epidermal surface of the trunk of reported species of Neoechinorhynchus, like those reported in other species of the Acanthocephala, and are associated with internal crypts and vary in diameter and distribution in different trunk regions, corresponding to differential absorption of nutrients. We have documented this phenomenon in 16 species of acanthocephalans [27]. The functional aspects of micropores in a few other acanthocephalan species including Rhadinorhynchus ornatus Van Cleave, 1918, Polymorphus minutus (Goeze, 1782) Lühe, 1911, Moniliformis (Bremser, 1811) Travassos (1915), Macracanthorhynchus hirudinaceus (Pallas, 1781) Travassos (1916, 1917), and Sclerocollum rubrimaris Schmidt and Paperna, 1978 were reviewed earlier [8]. We demonstrated the tunneling from the cuticular surface into the internal crypts by TEM. Wright and Lumsden [39] and Byram and Fisher [22] reported that the peripheral canals of the micropores are continuous with canalicular crypts. These crypts appear to "constitute a huge increase in external surface area implicated in nutrient uptake." Whitfield [38] estimated a 44-fold increase at a surface density of 15 invaginations per $1 \mu^{2}$ of Moniliformis moniliformis (Bremser, 1811) Travassos, 1915 tegumental surface. The micropores and the peripheral canal connections to the canaliculi of the inner layer of the tegument of Corynosoma strumosum (Rudolphi, 1802) Lühe, 1904 from the Caspian seal Pusa caspica (Gmelin) in the Caspian Sea were demonstrated by transmission electron micrographs [17].

\section{EDAX of hooks}

Most acanthocephalan hooks have three major elements: calcium, phosphorus, and sulfur [15, 16], among others, and small amounts of magnesium plus common protoplasm elements $(\mathrm{C}, \mathrm{N}, \mathrm{O}, \mathrm{H})$. The arched area at the base of the anterior hook of $N$. johnii exhibited high levels of calcium and phosphorus (Table 4, Fig. 21) very similar to the mammalian tooth with its layers. The X-ray scans of the gallium cut hooks help explain the morphological nature of $N$. johnii and identify its unique "personality." The uniqueness of the metal analysis as expressed by X-ray scans appear to be species-specific and can be regarded as finger prints of key diagnostic value that are just as important as molecular analysis. 


\section{Phylogenetic analysis}

Results consistently yielded a strongly supported distinct clade for the Neoechinorhynchus species from Vietnam for both $18 \mathrm{~S}$ and the ITS1-5.8-ITS2 region of ribosomal RNA. Phylogenetic analysis demonstrated that $N$. johnii occupies a separate position in the trees, probably indicating an Asian origin of this species. It has already been described in various studies that the genus Neoechinorhynchus harbors rich species diversity [3, 33, 34], but the lack of molecular data from the Asian region for species of Neoechinorhynchus demonstrates that the sampling of members of the genus, especially in Asia, is still incomplete. Previous molecular studies also reported paraphyly within the Palaeacanthocephala [28, 37], while findings related to monophyly in Eoacanthocephala are yet to be elucidated. Considering the results of the present study and the incompleteness of taxon sampling for species of Neoechinorhynchus, it would be very early to draw any conclusions regarding reconstruction of the evolutionary history of this group of acanthocephalans. Regarding the monophyletic and/or paraphyletic assemblage of $N$. johnii, we found that the sequences were not construed as a monophyletic assemblage in both regions (18S and ITS1-5.8S-ITS2) analyses. The present analyses show that the genus is paraphyletic and our phylogenetic trees corroborate the findings of other researchers [24, 34]. Thus, the genus Neoechinorhynchus requires more investigation as it has rich species diversity and, most likely, does not represent a monophyletic group. Therefore, this genus requires taxonomic revision with generation of more molecular data from additional species that will help to understand the phylogenetic relationships more clearly. In conclusion, our findings emphasize the importance of using both morphological and molecular methods when evaluating acanthocephalan diversity.

\section{Conflict of interest}

The authors declare that they have no conflict of interest.

Acknowledgements. This project was supported by the Department of Zoology, Chaudhary Charan Singh University, Meerut, India; the Department of Biology, Brigham Young University (BYU), Provo, Utah, United States; Vietnam National Program No. 47 under Grant code VAST.DA47.12/16-19, and by an Institutional Grant from the Parasitology Center, Inc. (PCI), Scottsdale, Arizona. We thank Naomi Mortensen, Bean Museum (BYU) for her expert help in the preparation and organization of plates and figures, and Michael Standing, Electron Optics Laboratory (BYU), for his technical help and expertise.

\section{References}

1. Amin OM. 1975. Variability in Acanthocephalus parksidei Amin, 1974 (Acanthocephala: Echinorhynchidae). Journal of Parasitology, 61, 307-317.

2. Amin OM. 2002. Revision of Neoechinorhynchus Stiles and Hassall, 1905 (Acanthocephala: Neoechinorhynchidae) with keys to 88 species in two subgenera. Systematic Parasitology, $53,1-18$.

3. Amin OM. 2013. Classification of the Acanthocephala. Folia Parasitologica, 60, 273-305.
4. Amin OM, Redlin MJ. 1980. The effect of host species on growth and variability of Echinorhynchus salmonis Müller, 1784 (Acanthocephala: Echinorhynchidae), with special reference to the status of the genus. Systematic Parasitology, 2, 9-20.

5. Amin OM, Ha NV. 2008. On a new acanthocephalan family and new order, from birds in Vietnam. Journal of Parasitology, 94, $1305-1310$.

6. Amin OM, Ha NV. 2011. On four species of echinorhynchid acanthocephalans from marine fish in Halong Bay, Vietnam, including the description of three new species and a key to species of Gorgorhynchus. Parasitology Research, 109, 841847.

7. Amin OM, Heckmann RA, Standing MD. 2007. Structuralfunctional relationship of the para-receptacle structure in Acanthocephala. Comparative Parasitology, 74, 383-387.

8. Amin OM, Heckmann RA, Radwan NA, Mantuano JS, Alcivar MAZ. 2009. Redescription of Rhadinorhynchus ornatus (Acanthocephala: Rhadinorhynchidae) from skipjack tuna, Katsuwonus pelamis, collected in the Pacific Ocean off South America, with special reference to new morphological features. Journal of Parasitology, 95, 656-664.

9. Amin OM, Heckmann RA, Ha NV. 2011. Description of two new species of Rhadinorhynchus (Acanthocephala: Rhadinorhynchidae) from marine fish in Halong Bay, Vietnam, with a key to species. Acta Parasitologica, 56, 67-77.

10. Amin OM, Heckmann RA, Ha NV, Luc PV, Doanh PN. 2000. Revision of the genus Pallisentis (Acanthocephala: Quadrigyridae) with the erection of three new subgenera, the description of Pallisentis (Brevitritospinus) vietnamensis subgen. et $\mathrm{sp}$. n., a key to species of Pallisentis, and the description of a new quadrigyrid genus, Pararaosentis gen. n. Comparative Parasitology, 67, 40-50.

11. Amin OM, Heckmann RA, Ha NV. 2004. On the immature stages of Pallisentis (Pallisentis) celatus (Acanthocephala: Quadrugyridae) from occasional fish hosts in Vietnam. Raffles Bulletin of Zoology, 52, 593-598.

12. Amin OM, Ha NV, Heckmann RA. 2008. New and already known acanthocephalans from amphibians and reptiles in Vietnam, with keys to species of Pseudoacanthocephalus Petrochenko, 1956 (Echinorhynchidae) and Sphaerechinorhynchus Johnston and Deland, 1929 (Plagiorhynchidae). Journal of Parasitology, 94, 181-189.

13. Amin OM, Ha NV, Heckmann RA. 2008. New and already known acanthocephalans mostly from mammals in Vietnam, with descriptions of two new genera and species of Archiacanthocephala. Journal of Parasitology, 94, 194-201.

14. Amin OM, Ha NV, Heckmann RA. 2008. Four new species of acanthocephalans from birds in Vietnam. Comparative Parasitology, 75, 200-214.

15. Amin OM, Ha NV, Ngo HD. 2011. First report of Neoechinorhynchus (Acanthocephala: Neoechinorhynchidae) from marine fish (Belonidae, Clupeidae, Megalopidae, Mugilidae, Sciaenidae) in Vietnamese waters, with the description of six new species with unique anatomical structures. Parasite, 18, 21-34.

16. Amin OM, Heckmann RA, Ha NV. 2011. Description of Heterosentis holospinus n. sp. (Acanthocephala: Arhythmacanthidae) from the striped eel catfish Plotosus lineatus in Halong Bay, Vietnam, with a key to species of Heterosentis and reconsideration of the subfamilies of Arhythmacanthidae. Comparative Parasitology, 78, 29-38.

17. Amin OM, Heckmann RA, Halajian A, El-Naggar AM. 2011. The morphology of an unique population of Corynosoma strumosum (Acanthocephala, Polymorphidae) from the Caspian seal, Pusa caspica, in the land-locked Caspian Sea using SEM, with special notes on histopathology. Acta Parasitologica, 56, 438-445. 
18. Amin OM, Heckmann RA, Ha NV. 2014. Acanthocephalans from fishes and amphibians in Vietnam, with descriptions of five new species. Parasite, 21, 53.

19. Amin OM, Saoud MFA, Alkuwari KSR. 2002. Neoechinorhynchus qatarensis sp. n. (Acanthocephala: Neoechinorhynchidae) from the blue-barred flame parrot fish, Scarus gobban Forsskål, 1775, in Qatar waters of the Arabian Gulf. Parasitology International, 51, 171-196.

20. Arthur JR, Te BQ. 2006. Check list of parasites of fishes of Vietnam. FAO Fisher Tech Paper 369/2. p. 123.

21. Bilqees FM. 1972. Descriptions of two Acanthocephala, including a new species Neoechinorhynchus karachiensis (Neoechinorhynchidea: Neoechinorhynchidae), from marine fishes of Karachi. Sind University Research Journal Science Series, 6, 93-100.

22. Byram JE, Fisher FM Jr. 1973. The absorptive surface of Moniliformis dubius (Acanthocephala). 1. Fine structure. Tissue and Cell, 5, 553-579.

23. Galazzo DE, Dayanandan S, Marcogliese DJ, McLaughlin JD. 2002. Molecular systematics of some North American species of Diplostomum (Digenea) based on rDNA-sequence data and comparisons with European congeners. Canadian Journal of Zoology, 80, 2207-2217.

24. García-Varela M, Pinacho-Pinacho CD. 2018 Dec. 3. Molecular characterization of Neoechinorhynchus cylindratus Van Cleave, 1913 (Acanthocephala: Neoechinorhynchidae), a parasite of the largemouth bass (Micropterus salmoides) in northern Mexico. Journal of Helminthology, 1-9, DOI: 10.1017/ S0022149X18001104.

25. Gupta NK, Jain M. 1983. On three already known species of the genus Neoechinorhynchus Hamann, 1892 (Acanthocephala) from fish in the Arabian Sea. Acta Parasitologica Polonica, 28, 407-416.

26. Hall TA. 1999. BioEdit: A user-friendly biological sequence alignment editor and analysis program for Windows 95/98/NT. Nucleic Acids Symposium Series, 41, 95-98.

27. Heckmann RA, Amin OM, El-Naggar AM. 2013. Micropores of Acanthocephala, a scanning electron microscopy study. Scientia Parasitologica, 14, 105-113.

28. Herlyn H, Piskurek O, Schmitz J, Ehlers U, Zischler H. 2003. The Syndermata phylogeny and the evolution of acanthocephalan endoparasitism as inferred from 18S rDNA sequences. Molecular Phylogenetics and Evolution, 26, 155-164.

29. Lee RE. 1992. Scanning electron microscopy and X-ray microanalysis. Englewood Cliffs, New Jersey: Prentice Hall. $458 \mathrm{p}$.
30. Littlewood DTJ, Olson PD. 2001. Small subunit rDNA and the phylum Platyhelminthes: Signal, noise, conflict and compromise, in Interrelationships of the Platyhelminthes. Littlewood DTJ, Bray RA, Editors. Taylor and Francis: London, UK. p. 262-278.

31. Milne I, Lindner D, Bayer M, Husmeier D, McGuire G, Marshall DF, Wright F. 2009. TOPALiv2: A rich graphical interface for evolutionary analyses of multiple alignments on HPC clusters and multi-core desktops. Bioinformatics, 25, 126-127.

32. Motomura H, Iwatsuki Y, Kimura S, Yoshino T. 2002. Revision of the Indo-West Pacific polynemid fish genus Eleutheronema (Teleostei: Perciformes). Ichthyological Research, 49, 47-61.

33. Pinacho-Pinacho $C D$, García-Varela $M$, Sereno-Uribe AL, Pérez-Ponce de León G. 2018. A hyper-diverse genus of acanthocephalans revealed by tree-based and non-tree-based species delimitation methods: Ten cryptic species of Neoechinorhynchus in Middle American freshwater fishes. Molecular Phylogenetics and Evolution, 27, 30-45.

34. Pinacho-Pinacho CD, Hernández-Orts JS, Sereno-Uribe AL, Pérez-Ponce de León G, García-Varela M. 2017. Mayarhynchus karlae n.g., n. sp. (Acanthocephala: Neoechinorhynchidae), a parasite of cichlids (Perciformes: Cichlidae) in southeastern Mexico, with comments on the paraphyly of Neoechynorhynchus Stiles \& Hassall, 1905. Systematic Parasitology, 94, 351-365.

35. Sasaki K. 2001. Sciaenidae. Croakers (drums), in FAO species identification guide for fishery purposes. The living marine resources of the Western Central Pacific. Volume 5. Bony fishes part 3 (Menidae to Pomacentridae). Carpenter KE, Niem VH, Editors. FAO: Rome. p. 2791-3380.

36. Tamura K, Stecher G, Peterson D, Filipski A, Kumar S. 2013. MEGA6: Molecular evolutionary genetics analysis version 6.0. Molecular Biology and Evolution, 30, 2725-2729.

37. Verweyen L, Klimpel S, Palm HW. 2011. Molecular phylogeny of the Acanthocephala (class Palaeacanthocephala) with a paraphyletic assemblage of the orders Polymorphida and Echinorhynchida. PLoS One, 6, e28285.

38. Whitfield PJ. 1979. The biology of parasitism: An introduction to the study of associating organisms. Baltimore, Maryland: University Park Press. 277 p.

39. Wright RD, Lumsden RD. 1969. Ultrastructure of the tegumentary pore-canal system of the acanthocephalan Moniliformis dubius. Journal of Parasitology, 55, 993-1003.

40. Yamaguti S. 1939. Studies on the helminth fauna of Japan. Part 29. Acanthocephala II. Japanese Journal of Zoology, Tokyo, 13, $317-351$

Cite this article as: Amin OM, Chaudhary A, Heckmann R, Ha NV \& Singh HS. 2019. Redescription and molecular analysis of Neoechinorhynchus (Neoechinorhynchus) johnii Yamaguti, 1939 (Acanthocephala, Neoechinorhynchidae) from the Pacific Ocean off Vietnam. Parasite 26, 43. 
Reviews, articles and short notes may be submitted. Fields include, but are not limited to: general, medical and veterinary parasitology; morphology, including ultrastructure; parasite systematics, including entomology, acarology, helminthology and protistology, and molecular analyses; molecular biology and biochemistry; immunology of parasitic diseases; host-parasite relationships; ecology and life history of parasites; epidemiology; therapeutics; new diagnostic tools.

All papers in Parasite are published in English. Manuscripts should have a broad interest and must not have been published or submitted elsewhere. No limit is imposed on the length of manuscripts.

Parasite (open-access) continues Parasite (print and online editions, 1994-2012) and Annales de Parasitologie Humaine et Comparée (1923-1993) and is the official journal of the Sociéte Française de Parasitologie. 